\title{
The Effect of Ureteral Stents on Postoperative Pain
}

\author{
Üreteral Stentlerin Postoperatif Ağrı Üzerine Etkisi
}

\begin{abstract}
Aim: We aimed to assess the postoperative pain after endoscopic ureter stone treatment according to the diameter of double J ureteral stents.

Materials and Methods: Our prospective randomized study included 63 patients with successful operation for unilateral ureter stone and DJ ureteral stent inserted. Patients were divided into 2 subgroups as aged under 40 years and over 40 years. These subgroups were randomized into $4.8 \mathrm{Fr}$ and $6 \mathrm{Fr}$ ureteral DJ stent groups preoperatively in double-blind manner. Patients had pain and other complaints recorded preoperative (preop), postoperative (po) 3rd, 7th days and 1 week after stent removal. Patient pain levels were determined using the numerical pain scale (NPS).

Results: For patients under 40 years of age, Group 1 had preop NPS score of $9.17 \pm 0.32$, while in Group 2 this was $9.79 \pm 0.15$ ( $p=0.099$ ), on po 3rd day NPS scores were $2.50 \pm 0.73$ and $7.36 \pm 0.45(p<0.05)$, on po 7 th day scores were $1.92 \pm 0.53$ and $2.57 \pm 0.48(p=0.428)$, and 1 week after DJ catheter removal scores were $0.08 \pm 0.08,0.57 \pm 0.23(p=0.087$ ), respectively. In both groups over 40 years of age, there were no significant differences in the NPS scores at these times. There were no significant differences identified between the groups for stone size and operation duration.

Conclusions: We think the use of $4.8 \mathrm{Fr}$ DJ catheters after endoscopic ureter stone treatment is more appropriate for pain control in the early po period, especially for young patients under 40 years of age. Additionally, we believe there is a need for more studies related to the necessity for use of ureteral stents and the features that optimal stents should have.

Keywords: Ureteral stent; ureter stone; ureterorenoscopy
\end{abstract}

\section{Öz}

Amaç: Çalıșmamızda Double J (DJ) üreteral stentlerin endoskopik üreter taș tedavisi sonrası postoperatif ağrı üzerine olan etkisini değerlendirmeyi amaçladık.

Gereç ve Yöntemler: Prospektif randomize çalıșmamızda tek taraflı üreter tașı nedeniyle başarılı bir șekilde opere edilen ve DJ üreteral stent yerleștirilen 63 hasta çalıșmaya dahil edildi. Hastalar yașlarına göre 40 yaș üzeri ve 40 yaș altı olmak üzere iki alt grupta değerlendirildi. Bu alt gruplar da preoperatif çift kör olarak 4.8 fr ve 6 fr üreteral DJ stent yerleștirilen gruplar olarak randomize edildi. Hastaların preoperative (preop), postoperative (po) 3. ve 7. gün ve stent çekildikten 1 hafta sonraki ağrı ve diğer șikayetleri kaydedildi. Hastaların ağrı düzeyleri Sayısal Ağıı Skalası(SAS) kullanılarak belirlendi.

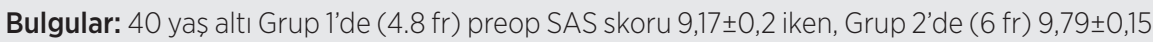
$(p=0,099)$ saptandı. Bu gruplarda po 3. gün SAS skoru sırasılyla 2,50 $\pm 0,73,7,36 \pm 0,45(p<0,05)$, po 7. gün sırasıyla $1,92 \pm 0,53,2,57 \pm 0,48(p=0,428)$ saptandı. DJ katater cekildikten 1 hafta sonra SAS skorları sırasıyla $0,08 \pm 0,08,0,57 \pm 0,23(p=0,087)$ idi. 40 yaș üstü her iki grupta da belirtilen zamanlarda bakılan SAS skorları arasında anlamlı bir fark bulunamadı. Ortalama taş boyutu ve operasyon süreleri açııından gruplar arasında anlamlı bir fark saptanmadı.

Sonuç: Özellikle 40 yaș altı genç hastalarda endoskopik üreter taș tedavisinde 4.8 Fr DJ katater kullanımının hastanın po erken dönemdeki ağrı kontrolü için daha etkili olduğu bulunmuştur. Ayrıca üreteral stentlerin kullanılmasının gerekliliği ve optimal stentlerin hangi özelliklere sahip olması gerektiği ile ilgili daha fazla çalıșmaya intiyaç duyulmaktadır.

Anahtar Sözcükler: Üreteral stent; üreter tașı; üreterorenoskopi
Mustafa Bilal Hamarat ${ }^{1}$, Fatih Ustun ${ }^{2}$, Serkan Ozcan ${ }^{3}$, Murat Bagcioglu ${ }^{4}$, Mehmet Kutlu Demirkol $^{5}$, Bekir Turgut ${ }^{6}$

1 Department of Urology, Saglik Bilimleri University Konya Training and Research Hospital

2 Sultanbeyli State Hospital

${ }^{3}$ Department of Urology, Izmir Katip Celebi University School of Medicine

${ }^{4}$ Department of Urology, Kafkas University School of Medicine,

${ }^{5}$ Department of Urology, Kahramanmaras Sutcu Imam University

${ }^{6}$ Department of Radiology, Saglik Bilimleri University Konya Training and Research Hospital

Received/Gelis : 14.08.2020 Accepted/Kabul: 03.12.2020

DOI: 10.21673/anadoluklin.778906

Corresponding author/Yazıșma yazarı Bilal Hamarat

Department of Urology, Saglik Bilimleri University Konya Training and Research Hospital, Konya, Turkey

E-mail: bilalhamarat@gmail.com

\section{ORCID}

M. Bilal Hamarat: 0000-0002-3987-7016 Fatih Ustun: 0000-0003-3551-2308 Serkan Ozcan: 0000-0002-2459-139X

Murat Bagcioglu: 0000-0003-4927-9164 M. Kutlu Demirkol: 0000-0003-1678-9889 Bekir Turgut: 0000-0001-8276-9996 


\section{INTRODUCTION}

The use of ureteral stents was published by Zimskind in 1967 and with the use of the modern double J (DJ) ureteral stent by Finley in 1978 (1). They began to be commonly used for many urologic procedures. DJ ureteral stents are frequently used to keep urinary drainage against ureteric obstruction and to preserve the continuity of the ureter. In addition, DJ stents can open the urinary tract during the endoscopic or open ureter interventions. There are different diameters, lengths and types of ureteral stents available, with no clear recommendations about the use of which diameter or length of stent in the literature. Nearly $75 \%$ of urologists report they routinely use DJ catheters after uncomplicated endoscopic stone surgery (2-4). In addition, the use of preoperative (preop) DJ ureteral stents has been reported in patients scheduled for flexible ureterorenoscopy (URS) surgery due to kidney stones (5). Ureteral stents prevent obstruction of the urinary system due to residual stone fragments and edema and hematoma developing postoperatively; however, they may lower patient quality of life due to vesicoureteral reflux, bladder and renal pelvis irritation. Complaints such as flank pain, irritative urinary symptoms, hematuria and sexual dysfunction are common after the insertion of the stents and these can reduce the patient's quality of life (6-8).

There was an attempt to assess symptoms encountered by patients due to stents with the Ureteral Stent Symptom Questionnaire (9). However, this questionnaire has less inclusion of pain level scales and symptom assessment. Meanwhile, a variety of scales are used to measure the patients' pain level. Among these scales, numerical scales are based on the patients expressing their pain as a number and make assessment of pain more objective. Numerical scales are frequently used due to the convenience of points systems and recording and being more useful for evaluation of floor and ceiling effects (10).

In our study, we aimed to comparatively assess the pain complaints developing linked to the use of 4.8 Fr and 6 Fr DJ ureteral stents inserted perioperatively after a successful endoscopic intervention using a numerical pain scale (NPS) (Figure 1).

\section{MATERIALS AND METHODS}

Our prospective randomized study included patients with operations planned to use semi-rigid ureterorenoscopy (URS) due to unilateral ureter stone attending two separate centers from 1 February 2016 to 1 November 2016. The local ethics committee of Kafkas University Faculty of Medicine approved our study. Informed consent regarding the procedure and their inclusion in the study was obtained from all patients. Preop imaging methods were direct urinary system radiography (DUSG), ultrasound and non-contrast abdomen computed tomography (CT). Patients were evaluated in two subgroups as those aged 40 years or older and 40 years or younger. These subgroups were randomized into 4.8 Fr and 6 Fr DJ stent groups preoperatively. Group 1, patients younger than 40 years and inserted 4.8 Fr DJ ureteral stent; group 2, patients younger than 40 years and inserted 6 Fr DJ ureteral stent; group 3, patients older than 40 years and inserted 4.8 Fr DJ ureteral stent; group 4, patients older than 40 years and inserted $6 \mathrm{Fr}$ DJ ureteral stent. The differentiation procedure for the groups was ensured by a nurse not working in the surgery giving 4.8 Fr DJ stent to one patient and 6 Fr DJ stent to another patient in mixed order.

All patients had endoscopic intervention performed with an 8-9.5 Fr rigid ureterorenoscope (Storz). Before the procedure, urine culture from patients was confirmed to be sterile and patients had preop secondgeneration cephalosporin prophylaxis administered. The endoscopic stone-fragmentation procedure was performed with laser (273 micron) and after stones were completely fragmented $(<3 \mathrm{~mm})$ patients had DJ ureteral stent insertion procedure performed in the lithotomy position. The DJ catheters were checked in the renal pelvis after the insertion with $\mathrm{x}$-ray. Postoperative (po) diclofenac potassium $1.25 \mathrm{mg} / \mathrm{kg} /$ day was given to patients for 10 days. Patients who did not insert stent, had migrating stent, had simultaneous renal stones, or had remnant stone were excluded.

Patients had NPS recorded by a person other than the surgeon, unaware of the groups, preop, on the postoperative 3rd and 7th days and 1 week after the stent was removed. Stents were removed after an average of two weeks. Some patients had stents removed early due to pain complaints in the early postoperative period. 
Table 1. Demographic data of patients aged 40 and under

\begin{tabular}{lccc}
\hline Age $\leq 40$ & $\begin{array}{c}\text { Group 1 } \\
\mathbf{( 4 . 8} \mathbf{~ f r})\end{array}$ & $\begin{array}{c}\text { Group 2 } \\
(\mathbf{6 ~ f r})\end{array}$ & $\mathbf{p}$ \\
\hline Gender (Male/Female) & $8 / 8$ & $10 / 5$ & 0.355 \\
\hline Age & $30.5 \pm 1.51$ & $29.8 \pm 1.55$ & 0.620 \\
\hline Lateralization (Right/Left) & $12 / 4$ & $7 / 8$ & 0.111 \\
\hline Stone Size $(\mathbf{m m})$ & $7.83 \pm 0.47$ & $7.79 \pm 0.50$ & 0.917 \\
\hline Operation Time (minute) & $38.08 \pm 2.93$ & $38.36 \pm 1.73$ & 0.959 \\
\hline
\end{tabular}

Table 2. Demographic data of patients older than 40 years

\begin{tabular}{lccc}
\hline Age $>$ 40 & $\begin{array}{c}\text { Group 3 } \\
(\mathbf{4 . 8} \mathbf{~ f r})\end{array}$ & $\begin{array}{c}\text { Group } \mathbf{4} \\
(\mathbf{6} \mathbf{f r})\end{array}$ & $\mathbf{p}$ \\
\hline Gender (Male/Female) & $9 / 8$ & $8 / 7$ & 0.982 \\
\hline Age & $54.06 \pm 1.76$ & $58.33 \pm 1.82$ & 0.15 \\
\hline Lateralization (Right/Left) & $5 / 12$ & $7 / 8$ & 0.322 \\
\hline Stone Size (mm) & $9.21 \pm 0.58$ & $8.91 \pm 0.49$ & 0.714 \\
\hline Operation Time (minute) & $43.79 \pm 3.20$ & $43.64 \pm 1.68$ & 0.978
\end{tabular}

Table 3. Numeric Pain Scale scores of patients under 40 years of age

\begin{tabular}{lccc}
\hline & $\begin{array}{c}\text { Group 1 } \\
\mathbf{( 4 . 8 ~} \mathbf{~ r})\end{array}$ & $\begin{array}{c}\text { Group 2 } \\
(\mathbf{6} \mathbf{~ f r})\end{array}$ & p \\
\hline Age $\leq$ 40 years (n) & 16 & 15 & \\
\hline Preop. NPS avg. & $9.17 \pm 0.32$ & $9.79 \pm 0.15$ & 0.099 \\
\hline PO 3. Day NPS avg. & $2.50 \pm 0.73$ & $7.36 \pm 0.45$ & $<\mathbf{0 . 0 5}$ \\
\hline PO 7. Day NPS avg. & $1.92 \pm 0.53$ & $2.57 \pm 0.48$ & 0.428 \\
\hline $\begin{array}{l}\text { After stent withdrawal } \\
\text { PO7. Day NPS avg. }\end{array}$ & $0.08 \pm 0.08$ & $0.57 \pm 0.23$ & 0.087 \\
$\begin{array}{l}\text { PO; postoperative, Preop; } \\
\text { preoperative, NPS; numeric } \\
\text { pain scale }\end{array}$ & & & \\
\hline
\end{tabular}

\section{Statistical Analysis}

The IBM SPSS v22 (IBM SPSS Inc., Armonk, NY, U.S.) was used for statistical analysis. We divided patients into two groups based on catheter size used (group 1 and group 2). Categorical variables were presented as numbers and percentages and compared with Chi Square test. All groups were compared according to NPS scores; conformity to normal distribution of the data was analyzed with histogram and P-P pilot test. The Mann-Whitney U and Kruskal Wallis tests were used to compare continuous variables that did not show normal distribution. A value of $\mathrm{p}<0.05$ was considered statistically significant.

\section{RESULTS}

Eighty-nine patients with unilateral endoscopic ureteral stone treatment were enrolled. Eleven patients with simultaneous renal stone, 1 patient with DJ catheter migration, 10 patients without DJ catheter insertion and 4 patients who were not stone-free were excluded from the study. The study included a total of 63 patients with successful operation for unilateral ureter stone and DJ ureteral stent inserted. Patients were divided into 2 groups as under and over 40 years. These groups were then subdivided into groups with $4.8 \mathrm{Fr}$ DJ ureteral stent and 6 Fr DJ ureteral stent inserted. Patients had pain complaints recorded preop, po 3rd and 7 th days and 1 week after stent removal.

The demographic values like sex, age, and mean stone size and operation durations were similar in the groups (Tables 1-2). For patients younger than 40 years, preop NPS score of Group 1 was $9.17 \pm 0.32$ while in Groups 2 it was $9.79 \pm 0.15(\mathrm{p}=0.099)$. On the po 3rd day, NPS scores were $2.50 \pm 0.73$, and $7.36 \pm 0.45$ $(\mathrm{p}<0.05)$, and on the po 7 th day scores were $1.92 \pm 0.53$, and $2.57 \pm 0.48(\mathrm{p}=0.428)$, respectively. One week after DJ catheters were removed, the NPS scores were $0.08 \pm 0.08$, and $0.57 \pm 0.23(\mathrm{p}=0.087)$, respectively. In Group 2, 3 patients had DJ catheter removed on the po 4th day due to severe pain linked to the DJ catheter and the po 7th day pain scores of these patients were not included in the assessment, but pain scores 1 week after DJ removal were included (Table 3).

For patients over 40 years of age, Group 3 preop NPS score was $8.57 \pm 0.46$ while it was $8.64 \pm 0.43$ $(\mathrm{p}=0.864)$ in Group 4 . On the po 3rd day NPS scores were $4.14 \pm 0.79$, and $2.82 \pm 0.40(\mathrm{p}=0.219)$, and on the po 7 th day scores were $3.57 \pm 0.85$, and $1.73 \pm 0.23$ $(\mathrm{p}=0.155)$, respectively. One week after DJ catheter removal, NPS scores were $1.14 \pm 0.68$ and $0.18 \pm 0.12$ $(\mathrm{p}=0.66)$, respectively (Table 4$)$.

In all groups pain after the operation reduced as the days passed and was observed to reach preop values with DJ stent removal. However, patients under 40 years of age with 4.8 Fr DJ inserted were observed to reach po 7 th day pain thresholds earlier compared to patients with $6 \mathrm{Fr}$ stent inserted.

When patients with 4.8 Fr DJ catheters inserted are compared among themselves, there was no significant difference identified between the NPS scores in Group 1 and Group 3 (Table 5). For patients with 6 Fr DJ catheter inserted, there was a significant difference between NPS scores on the po 3rd day $(\mathrm{p}<0.001)$. In 
other words, the group aged under 40 years with $6 \mathrm{Fr}$ DJ stent used were observed to have clearly high pain on the po 3rd day (Table 6).

\section{DISCUSSION AND CONCLUSION}

After URS operation, the use of DJ stents has become a routine procedure for many urologists, but the controversy about this topic continues (4). The European Association of Urology (EAU) guidelines do not recommend routine stent insertion for uncomplicated URS operations, while some studies have recommended individual assessment on a patient basis $(11,12)$.

A study by Canepa et al. examined pain complaints on the po 15th day after URS operation and showed patients without DJ stent inserted had fewer complaints compared to patients with stents (13). Additionally, a study by Damiano et al. examined visual pain values on the po 3rd day after URS operation and observed they were significantly low in patients with DJ stent compared to patients without stent (14). Another study by Bach et al. showed the use of short-term ureteral catheterization in URS operations caused less urinary symptoms and pain and lowered quality of life less compared to patients with DJ stent inserted (15). Sarı $\mathrm{S}$ et al. retrospectively analyzed patients who underwent flexible URS due to kidney stones. They used postoperative DJ stents in all patients and no major complications were reported (16). However, these studies did not pay attention to the different features of the DJ stents. According to a study grouped according to stent properties by Alkan Çubuk et al. after URS operations, Ureteral Stent Related Symptoms Questionnaire (USSQ) scores were significantly low both in the 1 st week po and after stent removal for the group without stent compared to the group with stent inserted (17). In our study, in general all groups had significant falls in NPS on the po 3rd and 7th days compared to preop values, and this fall was more pronounced in the NPS examined after stent removal (Tables 3, 4).

In the literature there are not many studies comparing DJ stents with different properties. A study in 1997 by Candela et al. compared 3 different stent types (4.8 Fr Hydroplus, 6 Fr Percuflex, and 6 Fr Hydroplus) and did not identify any significant differences in urinary symptoms and pain between these stents (18).
Table 4. Numeric Pain Scale scores of patients over 40 years

\begin{tabular}{lccc}
\hline & $\begin{array}{c}\text { Group 3 } \\
(\mathbf{4 . 8} \text { fr })\end{array}$ & $\begin{array}{c}\text { Group 4 } \\
(\mathbf{6 ~ f r})\end{array}$ & p \\
\hline Age $\mathbf{4 0}$ years $(\mathbf{n})$ & 17 & 15 & \\
\hline Preop NPS avg. & $8.57 \pm 0.46$ & $8.64 \pm 0.43$ & 0.864 \\
\hline PO 3. Day NPS avg. & $4.14 \pm 0.79$ & $2.82 \pm 0.40$ & 0.219 \\
\hline PO 7. Day NPS avg. & $3.57 \pm 0.85$ & $1.73 \pm 0.23$ & 0.155 \\
\hline $\begin{array}{l}\text { After stent withdrawal } \\
\text { PO7. Day NPS avg. }\end{array}$ & $1.14 \pm 0.68$ & $0.18 \pm 0.12$ & 0.66 \\
\hline PO; postoperative, Preop; preoperative, NPS; numeric pain scale
\end{tabular}

Table 5. Comparison of $4.8 \mathrm{fr} \mathrm{Dj}$ stent implantation of patients under 40 (Group1) and over 40 years (Group3)

\begin{tabular}{lccc}
\hline & $\begin{array}{c}\text { Group 1 } \\
(\mathbf{4 . 8} \text { fr })\end{array}$ & $\begin{array}{c}\text { Group 3 } \\
(\mathbf{4 . 8} \text { fr })\end{array}$ & p \\
\hline PO 3. Day NPS avg. & $2.50 \pm 0.73$ & $4.14 \pm 0.79$ & 0.112 \\
\hline PO 7. Day NPS avg. & $1.92 \pm 0.53$ & $3.57 \pm 0.85$ & 0.202 \\
\hline $\begin{array}{l}\text { After stent withdrawal } \\
\text { PO7. Day NPS avg. }\end{array}$ & $0.08 \pm 0.08$ & $1.14 \pm 0.68$ & 0.306 \\
\hline $\begin{array}{l}\text { PO; postoperative, NPS; numeric pain scale } \\
\end{array}$ & &
\end{tabular}

Table 6. Comparison of $6 \mathrm{fr} \mathrm{Dj}$ stent implantation of patients under 40 (Group 2) and over 40 years (Group 4)

\begin{tabular}{lccc}
\hline & $\begin{array}{c}\text { Group 2 } \\
(6 \mathrm{fr})\end{array}$ & $\begin{array}{c}\text { Gorup 4 } \\
(\mathbf{6} \text { fr })\end{array}$ & p \\
\hline PO 3. Day NPS avg. & $7.36 \pm 0.45$ & $2.82 \pm 0.40$ & $<0.001$ \\
\hline PO 7. Day NPS avg. & $2.57 \pm 0.48$ & $1.73 \pm 0.23$ & 0.102 \\
\hline $\begin{array}{l}\text { After stent withdrawal PO } \\
\text { 7. Day NPS avg. }\end{array}$ & $0.57 \pm 0.23$ & $0.18 \pm 0.12$ & 0.252 \\
\hline $\begin{array}{l}\text { PO; postoperative, NPS; } \\
\text { numeric pain scale }\end{array}$ & & & \\
\hline
\end{tabular}

Keun PH et al. in a study of symptoms linked to stents compared patients with Polaris and Percuflex stents inserted and did not identify a significant statistical difference in terms of USSQ scores and visual pain values (19).

Another study by Damiano et al. compared two groups with $4.8 \mathrm{Fr}$ and $6 \mathrm{Fr}$ DJ stents inserted and did not identify a clear difference between the two groups in terms of quality of life and urinary symptoms (3). A study by Agarwal et al. evaluated urinary symptoms related to 4, 5 and $6 \mathrm{Fr}$ DJ catheters and found patients in the group with $4 \mathrm{Fr}$ DJ catheter inserted had clearly low urinary symptom score and pain score on the 7 th day po, while the greatest reduction in pain scores after DJ catheter removal was observed in the 6 Fr group (20). The study by Alkan Çubuk et al., mentioned 
above, identified the USSQ scores of patients with 4.8 Fr DJ stent inserted were significantly low compared to patients with 6 Fr DJ stent inserted (17). In our study, evaluations between the groups found no clear difference for the groups aged over 40 years, but for patients aged under 40 years Group 1 using 4.8 Fr stent had significantly low NPS scores examined on the po 3rd day compared to Group 2 with 6 Fr stent used ( $<<0.05)$. Additionally, apart from Group 1, in the other groups significant degrees of reducing pain values were present compared to the previous assessment day, while in Group 1 po 7 th day pain values were reached on the po 3 rd day. This shows that patients aged under 40 years with 4.8 Fr DJ stent inserted reached po 7th day pain thresholds earlier compared to patients with 6 Fr DJ stent inserted. Evaluations of the 4 groups observed the total pain score was significantly higher in Group 2 compared to all other groups on the po 3rd day.

The limitation of this study is that the patients' degree of pain was not evaluated with other symptoms. Strong aspects of the study include being prospective and randomized, separate assessment of age groups, and a homogeneous patient population of patients undergoing the same operation.

Especially for young patients under 40 years of age, we think the use of 4.8 Fr DJ catheter after endoscopic ureter stone treatment is more appropriate for pain control in the early po period. Additionally, we believe there is a need for more studies related to the necessity to use ureteral stents and the properties an optimal stent should have.

\section{Competing Interests}

The authors declare that they have no competing interest.

\section{Financial Disclosure}

There are no financial supports

\section{Ethical Approval}

Ethics committee approval was received for this study from the Kafkas University School of Medicine Scientific Research Evaluation Board (27/04/2016) No: 80576354-050-99

\section{REFERENCES}

1. Finney RP. Experience with new double J ureteral catheter stent. J Urol. 1978;120(6):678-81.

2. Lingeman JE, Preminger GM, Goldfischer ER, Krambeck AE, Team CS. Assessing the impact of ureteral stent design on patient comfort. J Urol. 2009;181(6):2581-7.

3. Damiano R, Autorino R, De Sio M, Cantiello F, Quarto $\mathrm{G}$, Perdonà $\mathrm{S}$, et al. Does the size of ureteral stent impact urinary symptoms and quality of life? A prospective randomized study. Eur Urol. 2005;48(4):673-8.

4. Auge BK, Sarvis JA, L'Esperance JO, Preminger GM. Practice patterns of ureteral stenting after routine ureteroscopic stone surgery: a survey of practicing urologists. J Endourol. 2007;21(11):1287-92.

5. Öztekin Ü, Caniklioğlu M, Sercan S, Gürel A, Selmi V, Işıkay L, et al. Impact of preoperative stent on retrograde intrarenal surgery outcomes. KÜ Tip Fak Derg. 2020;22(1):89-95.

6. Damiano R, Oliva A, Esposito C, De Sio M, Autorino R, D’Armiento M. Early and late complications of double pigtail ureteral stent. Urol Int. 2002;69(2):136-40.

7. Miyaoka R, Monga M. Ureteral stent discomfort: Etiology and management. Indian J Urol. 2009;25(4):455-60.

8. Jeong H, Kwak C, Lee SE. Ureteric stenting after ureteroscopy for ureteric stones: a prospective randomized study assessing symptoms and complications. BJU international. 2004;93(7):1032-4.

9. Joshi H, Newns N, Stainthorpe A, MacDonagh R, Keeley F, Timoney A. Ureteral stent symptom questionnaire: development and validation of a multidimensional quality of life measure. J Urol. 2003;169(3):1060-4.

10. Johnson C. Measuring pain. Visual analog scale versus numeric pain scale: what is the difference? J Chiropr Med. 2005;4(1):43.

11. Türk C, Petřík A, Sarica K, Seitz C, Skolarikos A, Straub $\mathrm{M}$, et al. EAU guidelines on diagnosis and conservative management of urolithiasis. Eur Urol. 2016;69(3):468-74.

12. Muslumanoglu AY, Fuglsig S, Frattini A, Labate G, Nadler RB, Martov A, et al. Risks and benefits of postoperative double-J stent placement after ureteroscopy: results from the clinical research office of endourological society ureteroscopy global study. J Endourol. 2017;31(5):446-51.

13. Canepa G, Conzi G, Capponi G, Campodonico F, Maffezzini M. Short-time ureteral catheterization after operative ureteroscopic lithotripsy: an alternative to stent versus no stent evaluated in a retrospective study. Arch Ital Urol Androl. 2009;81(1):43-5. 
14. Damiano R, Autorino R, Esposito C, Cantiello F, Sacco $\mathrm{R}$, de Sio $\mathrm{M}$, et al. Stent positioning after ureteroscopy for urinary calculi: the question is still open. Eur Urol. 2004;46(3):381-7; discussion 7-8.

15. Bach P, Reicherz A, Teichman J, Dahlkamp L, von Landenberg N, Palisaar R-J, et al. Short-term external ureter stenting shows significant benefit in comparison to routine double-J stent placement after ureterorenoscopic stone extraction: A prospective randomized trial - the Fast track stent study (FaST). Int J Urol. 2018;25(8):717-22.

16. Sercan S, Selmi V, Caniklioğlu M, Öztekin Ü, Gürtan E, Işıkay L. Yozgat Bozok Üniversitesi 2-4 Cm Böbrek taşları tedavisinde retrograd intrarenal cerrahi deneyimimiz. Yozgat Bozok University retrograde intrarenal surgery experience for treatment of $2-4 \mathrm{~cm}$ kidney stones. Bozok Tip Derg.2020;10(1):150-53.
17. Cubuk A, Yanaral F, Ozgor F, Savun M, Ozdemir H, Erbin A, et al. Comparison of $4.8 \mathrm{Fr}$ and $6 \mathrm{Fr}$ ureteral stents on stent related symptoms following ureterorenoscopy: A prospective randomized controlled trial. Kaohsiung J Med Sci.2018;34(12):695-9.

18. Candela JV, Bellman GC. Ureteral stents: impact of diameter and composition on patient symptoms. J Endourol. 1997;11(1):45-7.

19. Keun PH, Hyun PS, Gon KH, Soo LY, Sangrak B. The impact of ureteral stent type on patient symptoms as determined by the ureteral stent symptom questionnaire: a prospective, randomized, controlled study. J Endourol. 2015;29(3):367-71.

20. Neeraj Agarwal AG, S S Yadav, Shivam, Priyadarshi RDS. Comparative analysıs of efficacy of different calibre of dj stent in relation to urinary tract symptoms. Ind J Res. 2018;7(3):3. 